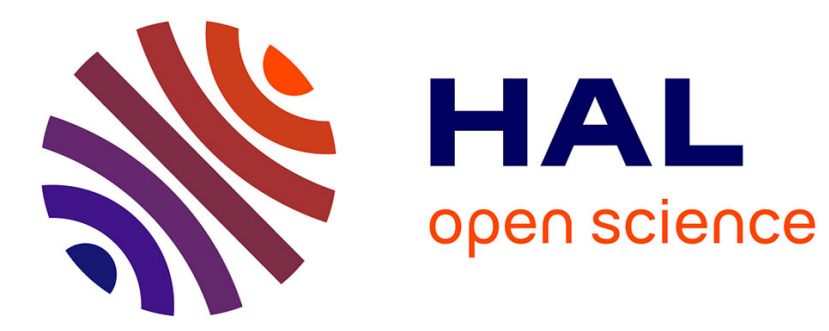

\title{
Repositories at Bibliodiversity Stakes: Community Approaches
}

\author{
Chérifa Boukacem-Zeghmouri, Christine Berthaud
}

\section{To cite this version:}

Chérifa Boukacem-Zeghmouri, Christine Berthaud. Repositories at Bibliodiversity Stakes: Community Approaches. ELPUB 2019 23rd edition of the International Conference on Electronic Publishing, Jun 2019, Marseille, France. 10.4000/proceedings.elpub.2019.8 . hal-02175233

\section{HAL Id: hal-02175233 \\ https://hal.science/hal-02175233}

Submitted on 5 Jul 2019

HAL is a multi-disciplinary open access archive for the deposit and dissemination of scientific research documents, whether they are published or not. The documents may come from teaching and research institutions in France or abroad, or from public or private research centers.
L'archive ouverte pluridisciplinaire HAL, est destinée au dépôt et à la diffusion de documents scientifiques de niveau recherche, publiés ou non, émanant des établissements d'enseignement et de recherche français ou étrangers, des laboratoires publics ou privés. 


\title{
Repositories at Bibliodiversity Stakes
}

\author{
Community Approaches
}

Chérifa Boukacem-Zeghmouri and Christine Berthaud

\section{Literature Overview}

1 Open Access is no longer a new story or a militant movement. The Green Road, represented by Open Repositories, is now deeply anchored in the scholarly communication system: through the behaviours of researchers, research infrastructures, the open access policies of publishers (Sherpa Romeo), research funding prescriptions, and publication standards.

2 For instance, Open Roar (http://roar.eprints.org/) now counts more than 4730 Open Repositories all over the world, archiving different types of documents. According to their size and typology, these repositories reflect the diversity of contexts (countries, institutions, research communities...) in which they were launched. They also reflect, through their new services (Knoth 2018) development and their visions for the future (Plutchak 2017). But, more importantly, Open Repositories form a part of a landscape that values openness from research communities (Neylon 2017), from national and European policies and from stakeholder strategies in an effort to build up Open Research Infrastructures for Open Science. Typically, evolution of thematic repositories is definitely part of a bibliodiversity where articles are not the only output (López-Borrull 2018), leaving room to new models (https://jussieucall.org/), new artefacts (Meadows 1985), linked and interlinked (Guéret 2013) (Next Generation Repositories: http:// ngr.coar-repositories.org).

325 years after the beginnings of Open Access and the launch of the very first repository ArXix (https://arxiv.org/), the latter has now tended to become a "brand" deployed to new fields which had not previously been viewed as compatible with repositories: agriculture, social sciences, psychology, and even biology. ArXiv "branding" deserves to be mentioned and observed: thematic repositories that rely on the "Arx" prefix are 
launched by research communities who cry out against publishers' strategies. SocarXiv ( https://socopen.org) is a typical example, as it was launched after SSRN was bought by Elsevier in 2016 (Jensen 2016). Communities of researchers have also expressed the will to become actors in the new dynamics linked to the reconfiguration of publication models (Pepe 2018).

In the meantime, openness is included in parts of a process in which complexity prevails in the contemporary scholarly communication system. "Historical" publishers are still present and with "Gold" Open Access publishers, the new kids on the block, they are launching Open Access journal catalogues (Morrison 2017). Plan S (Else 2018) is bringing a new policy dynamic to this road and providing a new opportunity to debate about the future of scholarly publishing. In the meanwhile, Megajournals are definitely a new hybrid journal category that contribute to the transition to the fully open access publication of science and innovate in the peer review process (Spezi 2017) (Perakakis 2010).

Predatory publishers are no longer an epiphenomenon and some researchers still publish their articles there, for good or bad reasons (Kurt 2018). ResearchGate, Academia and other academic social networks represent a new fringe of the publication industry. PDF sharing on these platforms are contested by the publishers and lead to legal battles for Copyright infringement (Chawla 2017). The contents of these platforms are indexed on Google Scholar, which is hugely used by researchers. The rankings of the results are a reflection of the place and visibility new stakeholders are gaining. Last but not least, "SciHub Lady", Alexandra Elbakyan, is using Open Access arguments to legitimize her "Robin Hood" piracy approach. As a corollary, studies have revealed that piracy has been trivialized in academia with millions of "globalized" downloads (Bohannon 2016; Nicholas 2018).

\section{Study's Key Objectives and Significance}

Open repository goals are at the crossroads of openness regulations. Regarding the reconfiguration of the scholarly communication landscape, the strategies adopted by repositories deserve to be examined. Openness is usually presented as a convergence vector wherein innovations, infrastructures and representation converge towards the same goal. Can we observe such a convergence when we look at the evolution of repositories? Moreover, what strategies do repositories adopt to keep up with their value when dealing with the openness era? What services and functionalities are developed to support their choices and missions? Our study seeks to identify and understand which strategies repositories have adopted in order to meet - or adjust - to Open Science requirements in terms of bibliodiversity. Understanding these issues is significant as we celebrate Open Science and we encourage researchers to practice it and adopt its values (Levin 2016).

\section{Design and Methodology}

1. In the state of the art, we left enough room to consider the various perspectives that govern innovation in the typology, developments and services of repositories. French, European and international literature is discussed to determine specificities and differences.

2. Based on a strategic analysis, a grid is set up and used to characterize a panel of 6 repositories from Europe and North America. 
3. Characteristics were then categorised and analysed to reveal and interpret the structural trend shaping the way panel repositories are currently directing their missions towards new publishing models and artefacts.

\section{Outcomes}

7 Results have shown that, while repositories are currently concentrated on infrastructure interoperability, on technology system integration and on archiving a wider typology of content (research data, software...), a main orientation has nevertheless emerged:

Thematic repositories are at the forefront of the publication process, from the very first phase, upstream of the prep-print, all the way to the publication process, until peerreviewing (Pepe 2018) (Guéret 2013). In this approach, services and functionalities are developed to help research communities shape the new publication models that best fit their needs. These repositories help communities gain more autonomy in handling the publication process and consider new artefacts as legitimate research outputs. This outcome highlight the well-known dichotomy between institutional and thematic repositories. Institutional repositories develop their roles by prioritizing consolidation of collections, directed more towards visibility and impact.

\section{Conclusion}

The study sheds light on the efforts and strategies conducted by a panel of thematic repositories to handle missions fostering openness and diversity of publishing models. This largely contribute to understand how thematic and community repositories are adjusting to Open Science requirements, and by this, contributing to bibliodiversity. At stake of this orientation, raise the issue of how these new artefacts will be linked, shared and retrieved. To conclude, we suggest reconsidering the term "repository" as it no longer seems relevant to our panel.

\section{BIBLIOGRAPHY}

Bohannon, J. 2016. “Who's downloading pirated papers? Everyone.” Science 352 (6285).

Chawla, D. S. 2017. "Publishers take ResearchGate to court, alleging massive copyright infringement." Science Magazine. October 6. http://www.sciencemag.org/news/2017/10/ publishers-take-researchgate-court-alleging-massive-copyright-infringement

Else, H. 2018. "Radical open-access plan could spell end to journal subscriptions." Nature 561:1718.

Guéret, C. 2013. "Digital archives as versatile platforms for sharing and interlinking research artefacts." In DPRMA '13 Proceedings of the 1st International Workshop on Digital Preservation of Research Methods and Artefacts, pp. 1-7. 
Jensen, M. C. 2016. Press Releases. https://www.ssrn.com/en/index.cfm/ssrn-joins-mendeleyelsevier/

Knoth, P., L. Anastasiou, A. Charalampous, M. Cancellieri, S. Pearce, N. Pontika, and V. Bayer. 2017. "Towards effective research recommender systems for repositories." http://arxiv.org/ abs/1705.00578

Kurt, S. 2018. "Why do authors publish in predatory journals?" Learned Publishing. http:// doi.org/10.1002/leap.1150

Levin, N., S. Leonelli, D. Weckowska, D. Castle., and J. Dupré. 2016. "How do scientists define openness? Exploring the relationship between open science policies and research practice." Bulletin of Science, Technology \& Society 36 (2): 128-141.

López-Borrull, A. 2018. Evolución de repositorios temáticos y megarrevistas: visión 2018. Anuario ThinkEPI 12:316-320.

Meadows, J. A. 1985. "The scientific paper as an archaeological artefact." Journal of Information Science 11 (1): 27-30.

Morrison, H. 2017. "From the field: Elsevier as an open access publisher." The Charleston Adviser 18 (3): 53-59. DOI: $10.5260 /$ chara.18.3.53

Neylon, C 2017. “Openness in scholarship: A return to core values?” In: Chan, L., and F. Loizides. (Eds.), Expanding Perspectives on Open Science: Communities, Cultures and Diversity in Concepts and Practices. IOS Press, pp. 6-17.

http://doi.org/10.3233/978-1-61499-769-6-6

Nicholas, D., C. Boukacem-Zeghmouri, J. Xu, E. Herman, D. Clark, A. Abrizah, B. Rodríguez-Bravo, and M. Świgoń. 2018. "Sci-Hub: The new and ultimate disruptor? View from the front." Learned Publishing 31 (4).

Perakakis, P., M. Taylor, M. Mazza, and V. Trachana. 2010. "Natural selection of academic papers." Scientometrics no. 85: 553-559.

Pepe, A., and M. Cantiello. 2018. "Why the ArXiv of the future will look like Authorea." (v3) Authorea. https://www.authorea.com/users/3/articles/168733-why-the-arxiv-of-the-future-willlook-like-authorea \\#

Plutckak, S., and K. B. Moore. 2017. "Dialectic: The aims of institutional repositories." The Serials Librarian 72:27-35. http://doi.org/10.1080/0361526X.2017.1320868

Spezi, V., S. Wakeling, S. Pinfield, J. Fry, C. Creaser, and P. Willett. 2017. "'Let the community decide?' The vision and reality of soundness-only peer review in open-access mega-journals." Journal of Documentation. 74 (1): 137-161

\section{ABSTRACT}

Green Road is deeply anchored in the scholarly communication system. Based on the analysis of a panel of 6 repositories, the study identify strategies repositories have adopted in order to meet or adjust to Open Science requirements in terms of bibliodiversity. Typically, thematic repositories are not only concerned with articles but also consider new artefacts, linked and interlinked. Research outcomes suggest reconsidering the term "repository" as it no longer seems relevant to our panel. 
INDEX

Keywords: repositories, openness, interoperability, brand, value, research communities, megajournals, bibliodiversity, artefacts

\section{AUTHORS}

\section{CHÉRIFA BOUKACEM-ZEGHMOURI}

Lyon University, Lyon 1, France

cherifa.boukacem-zeghmouri@univ-lyon1.fr

\section{CHRISTINE BERTHAUD}

CNRS - CCSD, France

christine.berthaud@ccsd.cnrs.fr 